\title{
Experience from a practical test of low-temperature district heating for space heating in five Danish single-family houses from the 1930s
}

Østergaard, Dorte Skaarup; Svendsen, Svend

Published in:

Energy

Link to article, DOI:

10.1016/j.energy.2018.06.142

Publication date:

2018

Document Version

Peer reviewed version

Link back to DTU Orbit

Citation (APA):

Østergaard, D. S., \& Svendsen, S. (2018). Experience from a practical test of low-temperature district heating for space heating in five Danish single-family houses from the 1930s. Energy, 159, 569-578.

https://doi.org/10.1016/j.energy.2018.06.142

\section{General rights}

Copyright and moral rights for the publications made accessible in the public portal are retained by the authors and/or other copyright owners and it is a condition of accessing publications that users recognise and abide by the legal requirements associated with these rights.

- Users may download and print one copy of any publication from the public portal for the purpose of private study or research.

- You may not further distribute the material or use it for any profit-making activity or commercial gain

- You may freely distribute the URL identifying the publication in the public portal 


\section{Accepted Manuscript}

Experience from a practical test of low-temperature district heating for space heating in five Danish single-family houses from the 1930s

Dorte Skaarup Østergaard, Svend Svendsen

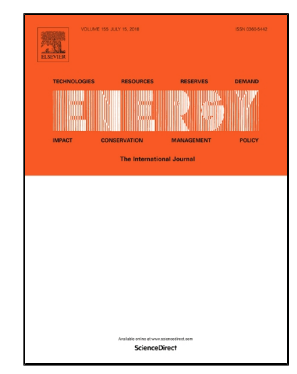

PII: $\quad$ S0360-5442(18)31207-6

DOI: $\quad 10.1016 / j$.energy.2018.06.142

Reference: $\quad$ EGY 13184

To appear in: $\quad$ Energy

Received Date: $\quad$ 08 February 2018

Accepted Date: $\quad 21$ June 2018

Please cite this article as: Dorte Skaarup Østergaard, Svend Svendsen, Experience from a practical test of low-temperature district heating for space heating in five Danish single-family houses from the 1930s, Energy (2018), doi: 10.1016/j.energy.2018.06.142

This is a PDF file of an unedited manuscript that has been accepted for publication. As a service to our customers we are providing this early version of the manuscript. The manuscript will undergo copyediting, typesetting, and review of the resulting proof before it is published in its final form. Please note that during the production process errors may be discovered which could affect the content, and all legal disclaimers that apply to the journal pertain. 
1 Experience from a practical test of low-temperature district heating for space heating in five Danish single-

2 family houses from the 1930s

3 Dorte Skaarup Østergaard*, Svend Svendsen

$4 \quad{ }^{*}$ Corresponding author, Tel. +45 4225 18 80, E-mail address: dskla@byg.dtu.dk.

5 Technical University of Denmark, Department of Civil Engineering, Brovej, Building 118, DK 2800 Kgs. Lyngby, Denmark.

6 Abstract:

7 The efficiency of district heating systems is greatly affected by network supply and return temperatures. However, the 8 opportunities to lower the temperatures and thereby increase network efficiency are restricted by customer installations. 9 Very little is known about the customer installations, because heating system operation is only rarely monitored in detail. 10 In this study, we therefore investigated the operation of the heating systems in five houses. The study had two aims: first

11 to investigate how much of the heating season the houses could be heated with supply temperatures as low as $55^{\circ} \mathrm{C}$, and 12 second to investigate whether occupant behaviour and heating system malfunctions caused unnecessarily high return 13 temperatures. The results showed that all the houses were compatible with low-temperature supply, and in two of the 14 houses return temperatures were even as low as the preferred $25-30^{\circ} \mathrm{C}$. Two main causes were found for unnecessarily 15 high return temperatures in the remaining houses: a few radiators were found to be too small, and thermostatic radiator 16 valves did not always ensure proper water mass flow. In conclusion, if these errors were corrected, the study indicates 17 that it would be possible to heat the investigated houses with district heating temperatures of $55 / 30^{\circ} \mathrm{C}$.

18 Keywords: Thermal comfort, hydraulic radiators, thermostatic radiator valves, heating system temperatures, occupant 19 behaviour 


\section{Introduction}

Proper heating system control has recently begun to attract attention as important for current attempts to reduce energy consumption in buildings. In areas provided by district heating, poor heating system control not only increases energy consumption inside the building, but can also lead to lower efficiency in the total energy system if it leads to higher district heating supply and return temperatures. Higher heating system temperatures have two implications for the district heating system: less efficient heat production and less efficient heat distribution. Firstly, the efficiency of most heat producing units decreases when operating temperatures are high. Low-temperature operation is therefore preferable for condensing boilers, heat pumps, and solar thermal heating systems [1]. Secondly, high operating temperatures have a negative impact on heat distribution efficiency, because high temperatures lead to greater heat losses from the piping network. A recent study suggests that overall heat loss could be reduced by $35 \%$ for an existing pipe network and as much as $75 \%$ for a new optimized network, if annual average supply and return temperatures can be reduced from $80 / 40{ }^{\circ} \mathrm{C}$ to $55 / 30{ }^{\circ} \mathrm{C}$ [2]. So, proper heating system control can lead to large savings in the energy system, especially in a country like Denmark, where more than $60 \%$ of homes are already heated by district heating [3] and district heating is expected to expand in the future [4]. Furthermore, proper heating system control is a prerequisite for the introduction of efficient low-temperature district heating, which is foreseen to play an important role in the future renewable energy system [5].

If proper heating system control is obtained, the heating system temperatures can be lowered according to the size of the heating elements and the heat demand of the building. Redesigning the entire existing heating system is costly, and therefore not a first option. However, recent research has indicated that most current radiators are large enough for existing buildings to be heated efficiently with low-temperature heating $[6,7]$. Simulations by Brand \& Svendsen and Wang et al. show that existing radiator systems can be used for low-temperature heating when just a few renovation measures are carried out $[8,9]$. Jangsten et al. and Averfalk et al. measured the overall radiator supply and return temperatures in Swedish and Swiss apartment buildings, and showed that some existing buildings could be operated with very low temperatures $[10,11]$. The studies additionally showed big differences in operation temperatures for the 
investigated buildings, which could indicate that there is a large potential to improve heating system control and move towards $4^{\text {th }}$ generation district heating, even for the current building stock.

Errors in the heating system control can be found already in the district heating substation or occur later in the internal heating system installations. Recent research suggests that there are errors in as much as $74 \%$ of district heating substations [12]. By use of automatic meter readings it is however possible to identify faults that may appear continuously [13] or even to improve the heat load patterns of the customers in order to improve the overall performance of the district heating system [14]. However, as illustrated by Petersson \& Werner [15], the internal heating system installations also play a major part in obtaining the lowest possible temperatures. Poor hydraulic balancing, incorrect valve sizes, and poor thermal length of heat exchangers are identified as typical errors in the internal heating system installations.

There may be three main reasons for the mentioned errors in the internal heating systems. Firstly, heating systems are often designed to cope with extreme weather conditions, which often means that the heating system is not optimally designed for the actual operating conditions. This can be especially problematic for the hydraulics in the heating system if the actual operation requires a water mass flow that differs greatly from the design mass flow. Secondly, a proper commissioning process is very rarely carried out in Denmark, which means that, if the heating system is not working as planned, errors and malfunctions will not necessarily be identified and corrected. Lastly, heating installations and building constructions may be gradually updated and modified, to a point where there is no longer an apparent relation between the design of the heating system and the heat demand of the building. The result is a mismatch between design and operation of the heating systems, as has been identified in several recent studies [11,16-18].

Recent studies have suggested that hydraulic balancing of the heating system and the use of thermostatic radiator valves (TRVs) provide good solutions to improve heating system control despite of the design issues. Monetti et al. showed that applying TRVs in an old Italian multi-family building led to energy savings of 2-10\% [19] while Ahern \& Norton describes how application of TRVs, hydraulic balancing and proper pump setting can lead to energy savings of up to $19 \%$ [18]. Cholewa et al. showed that installation of TRVs and use of pre-settings can lead to energy savings of around 20\% [20]. Trüschel showed how hydraulic balancing in three Swedish multi-family buildings could in some cases lead to 
energy savings, while other benefits included increased comfort or reduced heating system temperatures [21]. Similarly,

$\mathrm{Xu}$ et al. used dynamic modelling to show that the application of TRVs can help reduce heat consumption and problems

with overheating $[22,23]$. With regard to improving the heating system control, Tunzi showed how heating system

temperatures can be optimized through proper TRV control [24]. Piana et al. showed how the lack of hydraulic balancing or severe part load operation can lead to extreme excess flow-rates of $300 \%$ and $212 \%$ respectively in some radiators

[25]. The same tendency was found for floor heating systems, where Rhee et al. showed that use of TRVs and hydronic balancing is of great importance also for proper control of a hydronic floor heating system [26]. In conclusion, heating system performance can be greatly improved through improved control. Nevertheless, the solution is not bulletproof, and recent studies have also discussed the limitations of the current installations, and indicated that the stability and performance of TRVs can be easily compromised $[27,28]$.

While current research has dealt with this area, the main part of current knowledge is based on simulations, and in general, the importance of the heating system temperatures are neglected in favour of energy savings. Only little information is available on heating system temperatures inside buildings [11]. Furthermore, the measurements currently available are restricted to overall heating system temperatures, and do not indicate how the different parts of the heating system affect these overall temperatures. This study therefore provides new data on heating system temperatures in Danish single-family houses and reports novel and detailed investigations of how malfunctions that occur in buildings due to occupant behaviour or problems with specific in-house components can affect the potential to obtain low overall heating system temperatures. Such information is vital, if we are to identify the technical improvements that are needed to make existing heating systems work optimally and enable the use of low-temperature district heating.

This study had two main purposes: firstly, to make an investigation of the practical possibility of heating existing singlefamily houses with low-temperature heating, i.e. with a supply temperature of about $55^{\circ} \mathrm{C}$, and secondly, to identify and describe occupant behaviour and heating system malfunctions which may make it difficult to achieve lower district heating temperatures. The investigations were performed by monitoring the operation of the heating systems in five single-family houses and testing how the heating systems responded to lower supply temperatures. This paper includes 
94 discussion on how the heating system problems identified can be solved to enable existing houses to be heated with

95 low-temperature heating.

2 Method

\subsection{Description of the houses}

98 This research was based on a case study of five single-family houses from the 1930s. The houses are illustrated in Figure

99 1. The houses are all naturally vented and airtightness of the houses was not measured, but may be assumed to be around $0.5 \mathrm{~h}^{-1}$, which is the minimum ventilation rate required in the Danish building code and corresponds well with averages found for older dwellings [29]. The U-values of external walls, roofs, and windows are estimated to be approx. $0.78 \mathrm{~W} / \mathrm{m}^{2} \mathrm{~K}, 0.15-0.37 \mathrm{~W} / \mathrm{m}^{2} \mathrm{~K}$, and $1.5-2.8 \mathrm{~W} / \mathrm{m}^{2} \mathrm{~K}$ respectively. These values are based on a Danish catalogue of standard constructions, and U-values include thermal bridges [30]. Table 1 presents key information on the houses and their constructions. The heating systems in the houses consist of hydraulic radiators - the most common type of heating system in existing Danish single-family houses. The radiators are located as shown in the floor plans of the houses and a description of the types of radiator and their estimated heating power at the temperature set $90 / 70 / 20^{\circ} \mathrm{C}$ is given in Table 2. Additional electric floor heating is installed in the first-floor bathroom of House 1 and in both bathrooms of House 3. The houses represent different architectural styles, and they differ in types of occupant and in heated floor area. 

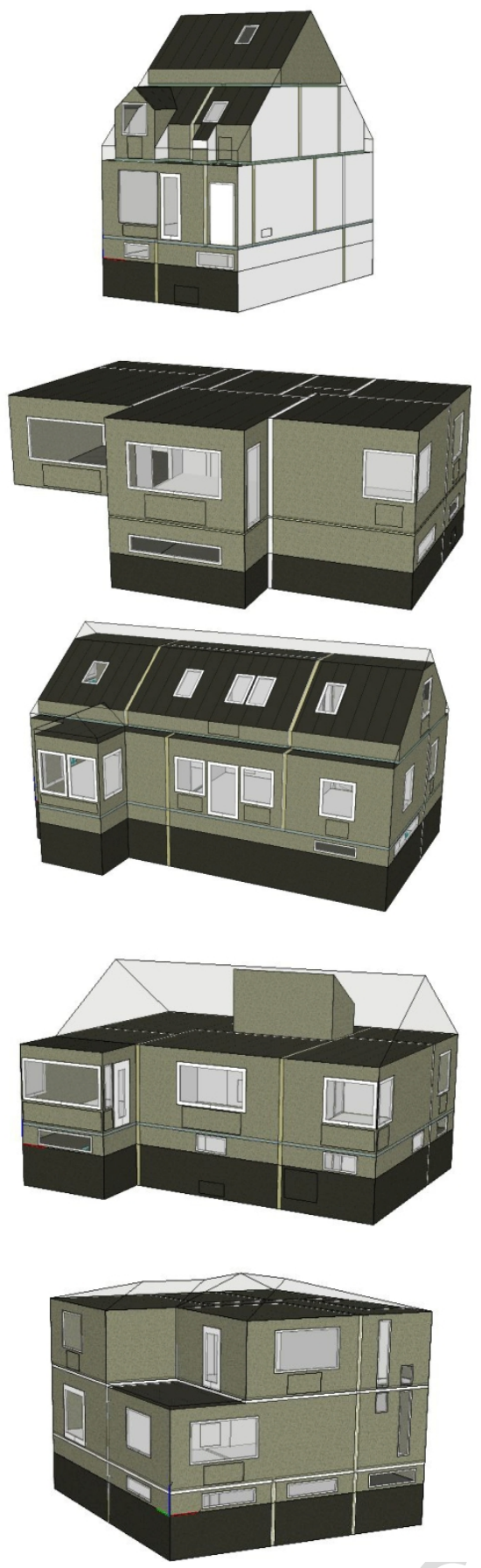

\section{Table 1}

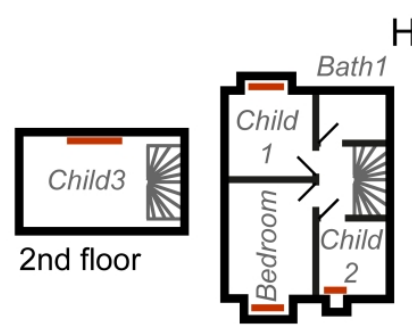

HOUSE 1

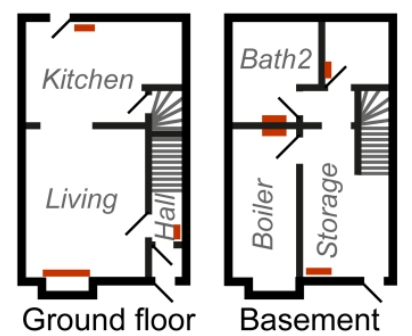

HOUSE 2

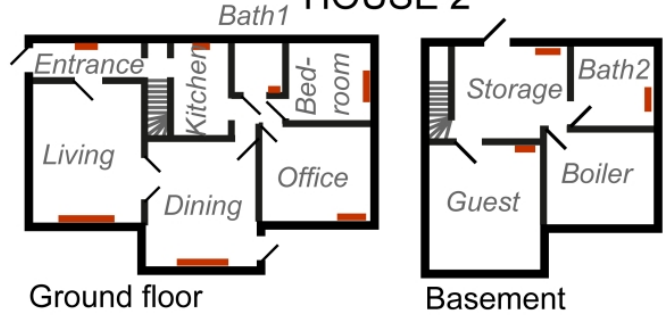

HOUSE 3 Bath1
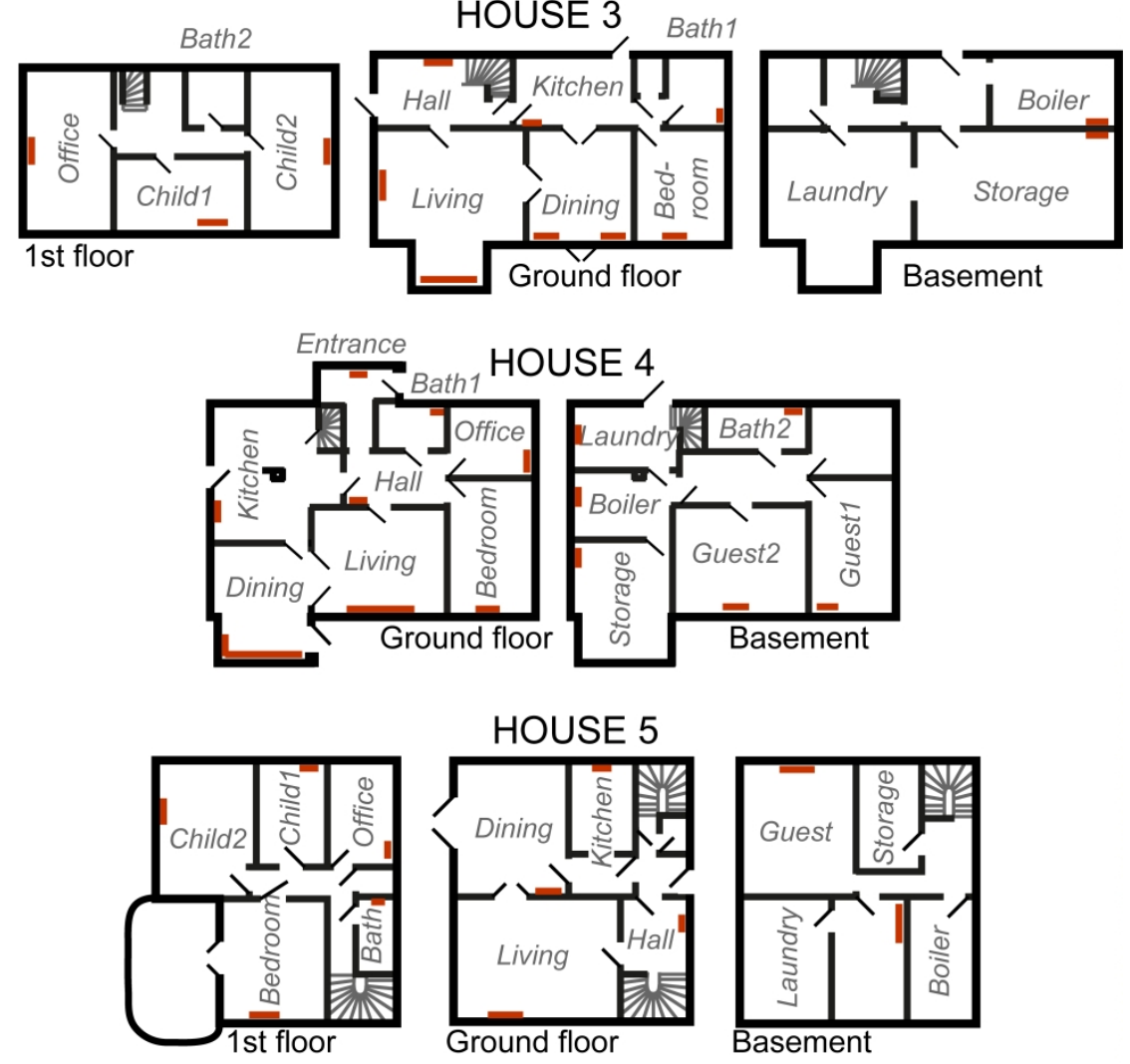

Figure 1 The five houses investigated in the study. The red lines on the floor plans indicate the location of radiators.

Key data for the houses investigated. All areas are based on external measurements as is the custom in Denmark.

\begin{tabular}{|l|c|c|c|c|c|}
\hline \multicolumn{1}{|c|}{ House: } & $\mathbf{1}$ & $\mathbf{2}$ & $\mathbf{3}$ & $\mathbf{4}$ & $\mathbf{5}$ \\
\hline No. of occupants & $1-5$ & 2 & 2 & 2 \\
\hline $\begin{array}{l}\text { Floor area / } \\
\text { basement area }\end{array}$ & $150 \mathrm{~m}^{2} / 48 \mathrm{~m}^{2}$ & $165 \mathrm{~m}^{2} / 69 \mathrm{~m}^{2}$ & $320 \mathrm{~m}^{2} / 118 \mathrm{~m}^{2}$ & $241 \mathrm{~m}^{2} / 118 \mathrm{~m}^{2}$ & $202 \mathrm{~m}^{2} / 107 \mathrm{~m}^{2}$ \\
\hline Heated basement & $48 \mathrm{~m}^{2}$ & $55 \mathrm{~m}^{2}$ & $47 \mathrm{~m}^{2}$ & $110 \mathrm{~m}^{2}$ \\
\hline External walls & \multicolumn{5}{|c|}{ Cavity brick wall with cavity wall insulation $\left(\mathrm{U}=0.78 \mathrm{~W} / \mathrm{m}^{2} \mathrm{~K}\right)$} \\
\hline
\end{tabular}




\begin{tabular}{|c|c|c|c|c|c|}
\hline Basement floor/ & \multicolumn{5}{|c|}{$20 \mathrm{~cm}$ concrete towards ground $\left(\mathrm{U}=0.48 \mathrm{~W} / \mathrm{m}^{2} \mathrm{~K}\right) / 30 \mathrm{~cm}$ concrete $\left(\mathrm{U}=1.1 \mathrm{~W} / \mathrm{m}^{2} \mathrm{~K}\right)$} \\
\hline Roof insulation & $\begin{array}{l}20 \mathrm{~cm} \text { insulation } \\
\left(\mathrm{U}=0.2 \mathrm{~W} / \mathrm{m}^{2} \mathrm{~K}\right)\end{array}$ & $\begin{array}{c}10 \mathrm{~cm} \text { insulation } \\
\left(\mathrm{U}=0.37 \mathrm{~W} / \mathrm{m}^{2} \mathrm{~K}\right)\end{array}$ & $\begin{array}{l}25 \mathrm{~cm} \text { insulation } \\
\left(\mathrm{U}=0.15 \mathrm{~W} / \mathrm{m}^{2} \mathrm{~K}\right)\end{array}$ & $\begin{array}{l}20 \mathrm{~cm} \text { insulation } \\
\left(\mathrm{U}=0.2 \mathrm{~W} / \mathrm{m}^{2} \mathrm{~K}\right)\end{array}$ & $\begin{array}{l}20 \mathrm{~cm} \text { insulation } \\
\left(\mathrm{U}=0.2 \mathrm{~W} / \mathrm{m}^{2} \mathrm{~K}\right)\end{array}$ \\
\hline $\begin{array}{l}\text { Windows main } \\
\text { floor/basement }\end{array}$ & \multicolumn{3}{|c|}{$\begin{array}{l}\text { 2-pane energy glazing } \\
\left(\mathrm{U}=1.5-1.6 \mathrm{~W} / \mathrm{m}^{2} \mathrm{~K}\right)\end{array}$} & $\begin{array}{c}\text { double glazing } / 1 \\
\text { pane } \\
\left(\mathrm{U}=2.3 / 4.3 \mathrm{~W} / \mathrm{m}^{2} \mathrm{~K}\right)\end{array}$ & $\begin{array}{c}\text { Mix of 2-pane energy } \\
\text { glazing and 2-pane } \\
\text { windows }(\mathrm{U}=1.5 \text { - } \\
\left.2.7 \mathrm{~W} / \mathrm{m}^{2} \mathrm{~K}\right)\end{array}$ \\
\hline
\end{tabular}

Table 2

Description of types of radiator (plane, panel, column, or convector) and heating power $\left(90 / 70 / 20{ }^{\circ} \mathrm{C}\right)$ in the rooms of the houses

\begin{tabular}{|c|c|c|c|c|c|}
\hline & HOUSE 1 & HOUSE 2 & HOUSE 3 & HOUSE 4 & HOUSE 5 \\
\hline Living room & Panel-2203W & Column - $3234 \mathrm{~W}$ & Panel-6164 W & Panel-2278 W & Column - $4054 \mathrm{~W}$ \\
\hline Dining room & Column - 1830 W & Column - 2904 W & Panel-4231 W & Panel-4235 W & Column - 2976 W \\
\hline Kitchen & & Panel - 444 W & Panel-1974 W & Panel -865 W & Plane - 776 W \\
\hline Bedroom & Column - 1830 W & Panel-1511 W & Panel-1705 W & Panel-2535 W & Column - $2849 \mathrm{~W}$ \\
\hline Child & Column - 1677 W & & Panel-2569 W & 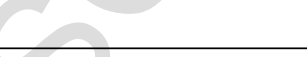 & Column - $1382 \mathrm{~W}$ \\
\hline Child2 & Column-1525 W & & Panel-2136 W & & Column - $2849 \mathrm{~W}$ \\
\hline Child3 & Convector - $1973 \mathrm{~W}$ & & & & \\
\hline Bathroom & & Plane-553 W & Panel-1058 W & Panel - 886 W & Column - $1290 \mathrm{~W}$ \\
\hline Office & & Panel - 1705 W & Panel-2569 W & Column - $1340 \mathrm{~W}$ & Column - $1808 \mathrm{~W}$ \\
\hline Entrance & Convector $-520 \mathrm{~W}$ & Panel-1295 W & Panel-1705 W & Panel - $585 \mathrm{~W}$ & \\
\hline Hall & & & 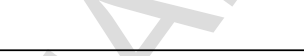 & Column - $852 \mathrm{~W}$ & Column - $2027 \mathrm{~W}$ \\
\hline Boiler room & Panel-1490 W & Panel - 1295 W & Panel - 1511 W & Panel-1364 W & \\
\hline Laundry & & & 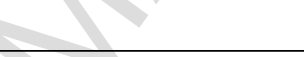 & Panel-1364 W & Panel - 5345 W \\
\hline Storage room & Panel-2116 W & Panel - 1295 W & Column - $2470 \mathrm{~W}$ & Panel-1364 W & Panel - 1562 W \\
\hline Guest room & & Panel - 1727 W & & Panel-1574 W & \\
\hline Guest room2 & & & & Panel-2578 W & \\
\hline Bathroom2 & Panel-1058 W & & & Panel - 866 W & \\
\hline Shed & Panel - $553 \mathrm{~W}$ & 8 & & & \\
\hline
\end{tabular}

Heating is provided to the houses from a newly established district heating system, and the heat is delivered via a

district heating substation. The substation was developed for low-temperature operation and has been tested and

described in recent research [31,32]. A sketch of the substation can be seen in Figure 2. Domestic hot water for each

house is prepared through a direct heat exchanger, which reduces the risk of legionella, even when supply temperatures

are reduced to $50^{\circ} \mathrm{C}$. Space heating is provided through a separate heat exchanger. The space-heating supply

temperature is weather-compensated, so the supply temperature varies with outdoor temperature depending on the

proportional control and individual thermostatic radiator valves. 
District heating

Outdoor

temperature

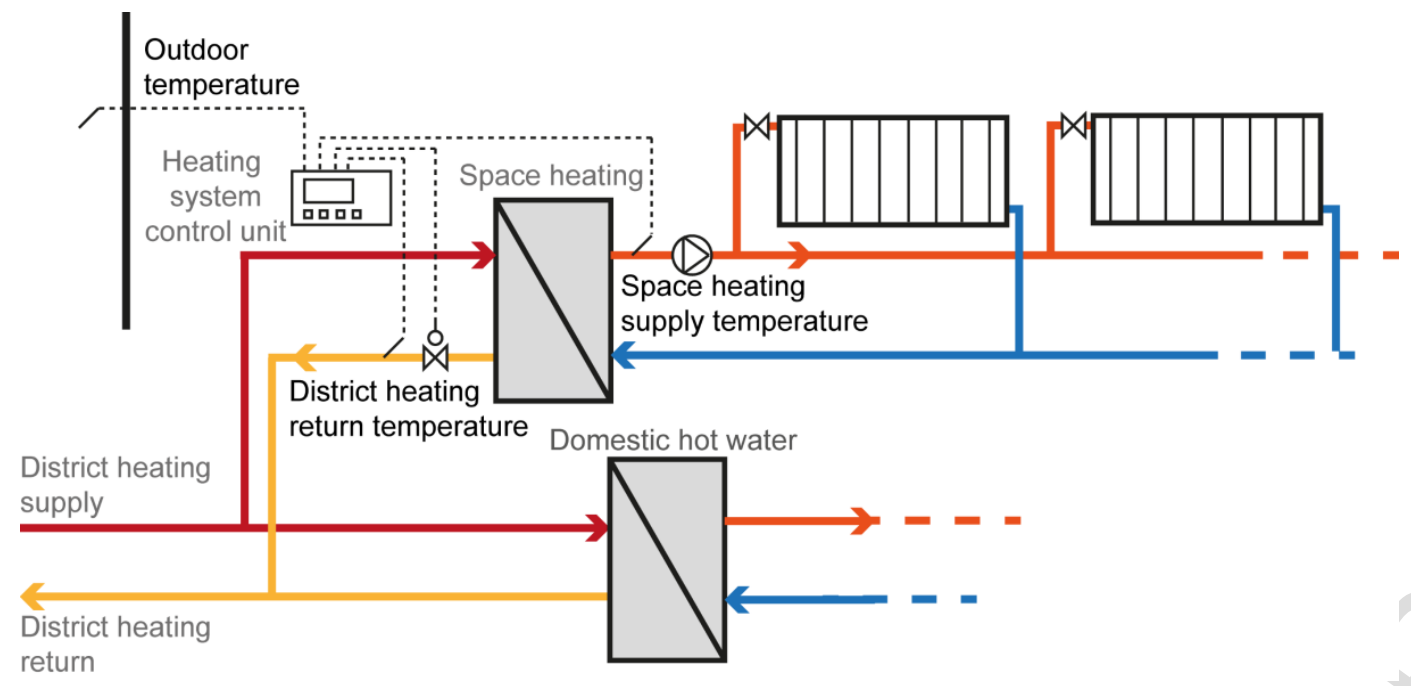

Figure $\mathbf{2}$ Layout of low-temperature district heating substation with indirect connection

\subsection{Measurements and monitoring}

Measurement equipment was installed in the houses at the beginning of the heating season 2015-2016 to investigate how the operation of the heating system affected the heating of the houses with low-temperature district heating. All temperatures were measured using equipment connected to a wireless network, which made it possible to supervise the operation of the heating system in real time. Three different types of temperatures were measured:

- radiator return temperatures (Tr)

- indoor temperatures (Ti)

- $\quad$ overall space heating $(\mathrm{SH})$ and district heating $(\mathrm{DH})$ temperatures

Radiator return temperatures, overall space heating temperature, and indoor temperatures were measured by use of

Brunata FuturaComfort+ loggers [33] that are approved according to European norms DS/EN ISO 9001 [34] and DS/EN

834 [35]. The loggers have an accuracy of $\pm 0.5^{\circ} \mathrm{C}$ according to the manufacturer. Additionally space heating and district

temperature sensors [37].

Return temperatures from all operating radiators in each house were measured on an hourly basis to identify where

errors or malfunctions occurred in the heating systems. Every logger was equipped with a probe mounted on the 
outside of the return pipe of the individual radiator. The probes and pipes were covered with insulation and tape, as

illustrated in Figure 3, to reduce the effect of the surrounding air temperature. A comparison between the temperatures

measured using this method and temperatures measured using a laser thermometer showed that the method

underestimates return temperatures by $2.4-5.4{ }^{\circ} \mathrm{C}$ on average, so these measurements were not entirely precise, but

they made it possible to evaluate the operation of the heating system and identify radiators with high return

temperatures.

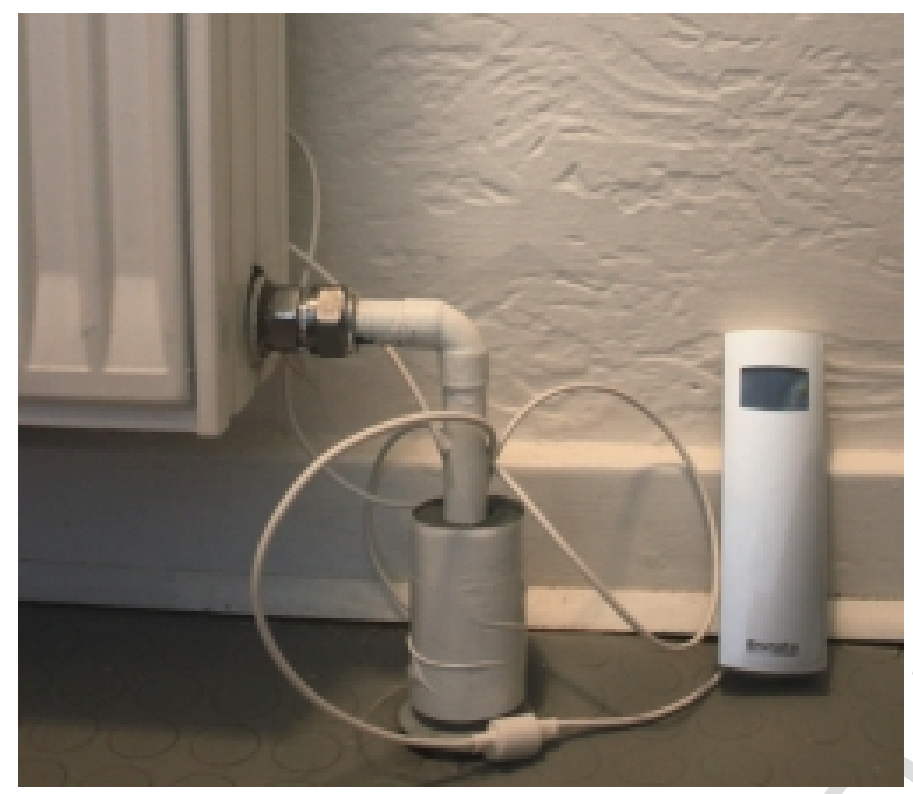

Figure 3 Equipment setup for the measurement of return temperatures from radiators

The indoor temperatures in the rooms of the houses were measured to evaluate the thermal comfort. The

measurements were taken using the same type of loggers as the radiator return temperatures, except that they were equipped with an internal probe to measure the surrounding air temperature. The loggers were generally placed on furniture near internal walls at heights between $0.5 \mathrm{~m}-2.0 \mathrm{~m}$. The maximum room height was $2.75 \mathrm{~m}$. These locations ensured a reasonable estimate of the average room air temperature; earlier studies have shown that the vertical temperature gradient under these conditions is no more than $0.3^{\circ} \mathrm{C}[38,39]$. The indoor temperature measurements gave an indication of the set-points of the thermostatic radiator valves and made it possible to evaluate the relationship between indoor temperature requirements and the operation of the heating system. 
Measurements of the outdoor temperature and the supply and return temperatures in the space heating and district heating system were carried out every 15 minutes in four of the houses. In House 2 it was regretfully not possible to make these measurements, since the occupants did not agree to put up this additional measurement equipment. The measurements were obtained from the heating system controller unit (see Figure 2). Due to logger failures and connection problems, measurements are not available for the entire heating season. Nevertheless, comparison of these measurements with the radiator return temperatures made it possible to investigate the effect that each individual radiator had on the overall operation of the heating system.

The measurements were all instant temperature measurements, so they do not take water mass flow into account. Average temperatures calculated based on the measurements were therefore time-weighted averages and not volumeweighted. This type of measurement will give a realistic picture of the operation of the heating system when the water flow in the heating system is more or less steady. This was generally found to be the case for the measurements presented, but the proviso should be kept in mind before drawing conclusions from the results.

\subsection{Occupant contact}

The occupants in the houses were regularly asked about their satisfaction with the space heating, and they were given the option to contact the researchers on phone or e-mail if they experienced any problems or discomfort. Therefore part of the heating system issues were identified through measurements, whereas part of them were identified when occupants took contact to ask about implications with thermal comfort. An example of the latter was, that some occupants contacted the authors as they felt cold in the beginning of the heating season. This was found to be due to the fact that valves were stuck, and the problem was quickly fixed to ensure the thermal comfort. If a high return temperature from one radiator was noticed in the measurements on the other hand, the researchers took contact to the occupants to ask about the specific circumstances for the given radiators. This would for example lead to the specification that a radiator thermostat had been turned up, to removed moisture from a basement room, or because occupants felt a cold draft from the entrance door. In this way occupant contact helped ensure that thermal comfort was maintained during the measurement period, and classify problematic conditions that might not have been identified through measurements. 


\section{Results}

The following sections present the results from the measurements in the single-family houses investigated. The first section reports the overall heating system supply and return temperatures measured in the houses. The second section describes the errors and malfunctions in the heating system design and control that were identified through the measurements, and how these affected the resulting return temperatures.

\subsection{Heating system supply and return temperatures}

Figure 4 shows the outdoor temperature and space-heating supply and return temperatures measured in Houses 1, 3, 4, and 5 from October 2015 to March 2016. The measurements are not available for House 2, since the occupants did not agree to put up additional loggers, and due to logger failures, measurements are not available for the entire period. The space heating supply temperatures measured correspond well with the targets of low-temperature district heating, being generally below $55-60^{\circ} \mathrm{C}$, but increasing in cold periods. No supply temperature optimization was carried out during the study, so it may be possible to reduce the supply temperature further. The return temperatures correspond to the preferred $25-30^{\circ} \mathrm{C}$ in two of the houses. In general, these results indicate that low-temperature district heating can be used for space heating in existing single-family houses, but that measures will be needed in some houses to achieve low average return temperatures. 

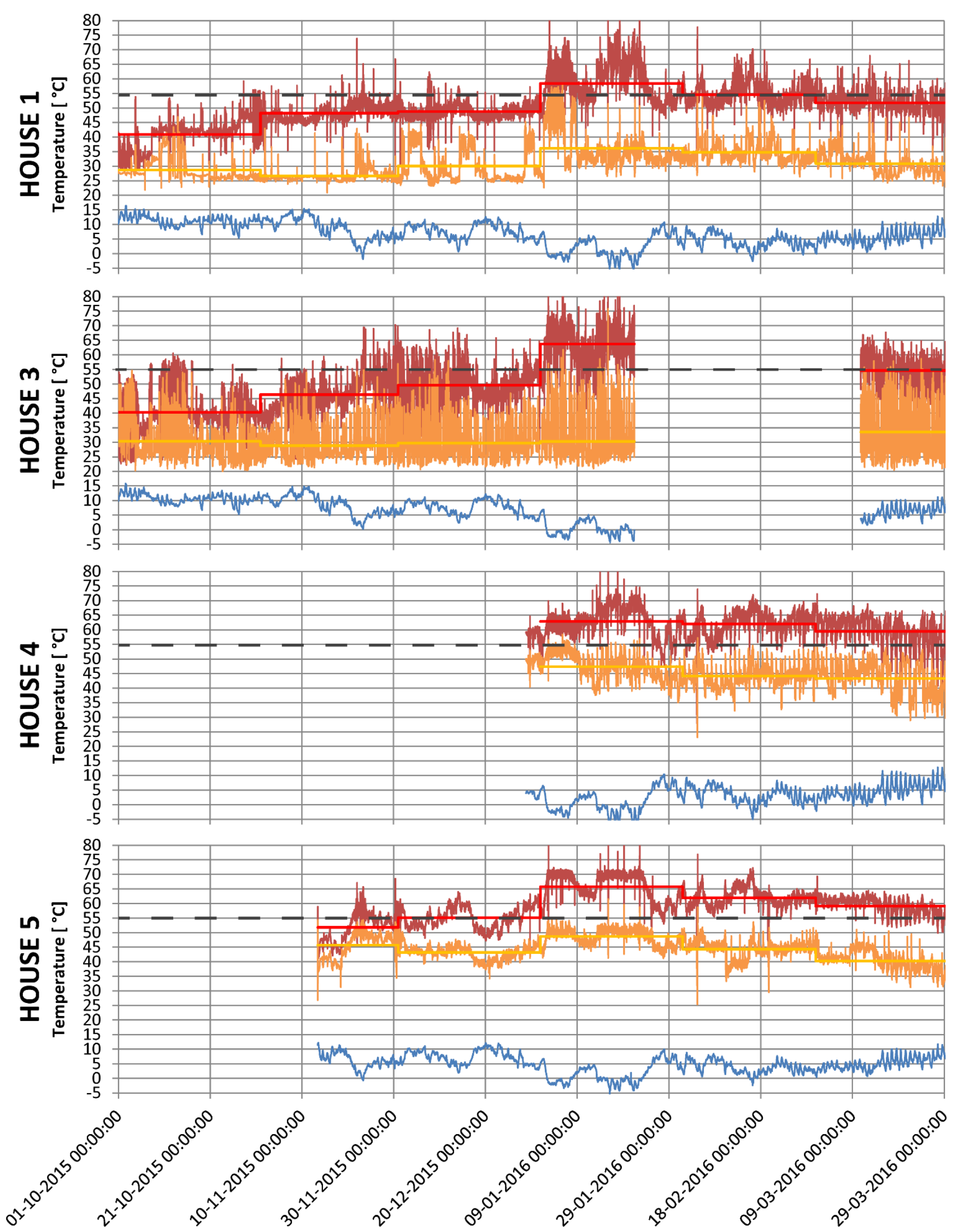

- Space heating supply _-Districy heating return - Outdoor air temperature

- Average space heating supply $\quad$ Average district heating return - - Reference of $55^{\circ} \mathrm{C}$

Figure 4 Heating system temperatures in Houses 1, 3, 4, and 5. 
The overall return temperature is a product of the individual radiator return temperatures in the houses. Average

radiator return temperatures and space heating return temperatures from $1^{\text {st }}$ September 2015 to $1^{\text {st }}$ April 2016 are

illustrated in Figure 5. It should be kept in mind that these temperatures only provide an indication of the radiator return temperatures due to the uncertainties of the measurement method and the limitations of time-averaged values that do not take water mass flow into account. The measurements show that only a few radiators were unable to achieve a low return temperature, but that these had a large impact on the overall return temperature. For example in House 2 the overall space heating return temperature was measured to around $37^{\circ} \mathrm{C}$ even though only three out of 10 radiators had a return temperature above $32{ }^{\circ} \mathrm{C}$. This indicates that overall the heating systems may be compatible with low return temperatures, but that local problems must be resolved to achieve an overall low return temperature.

HOUSE 1

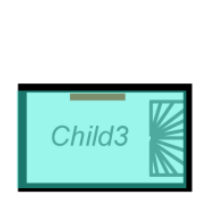

2nd floor

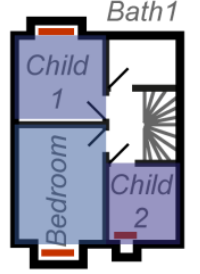

1st floor

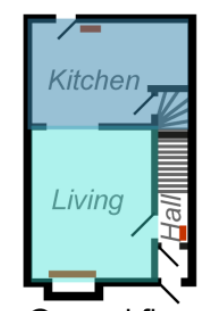

Ground floor

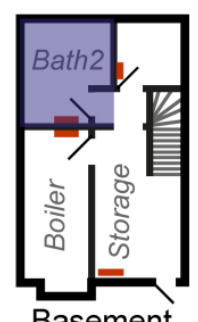

Basement

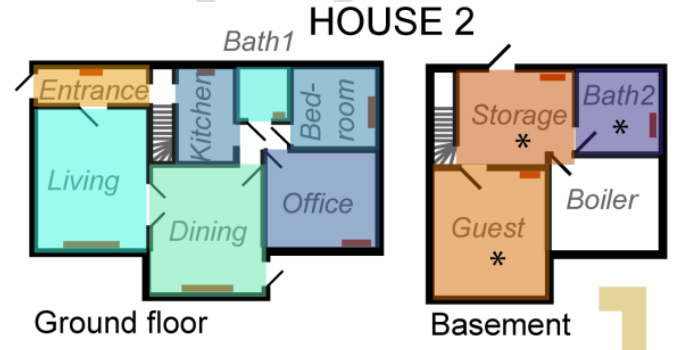

Ground floor
Basement

Overall return

- HOUSE 2

Overall return

- HOUSE 5 - HOUSE 1

Overall return - HOUSE 3
Overall return

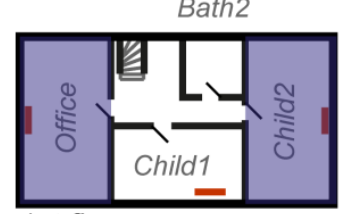

1st floor
HOUSE 3

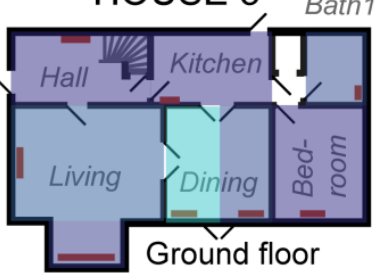

Ground floor

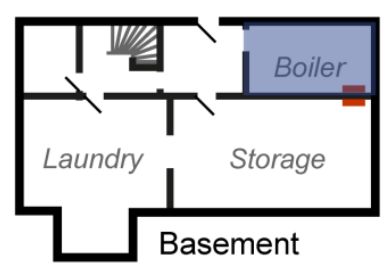

HOUSE 5

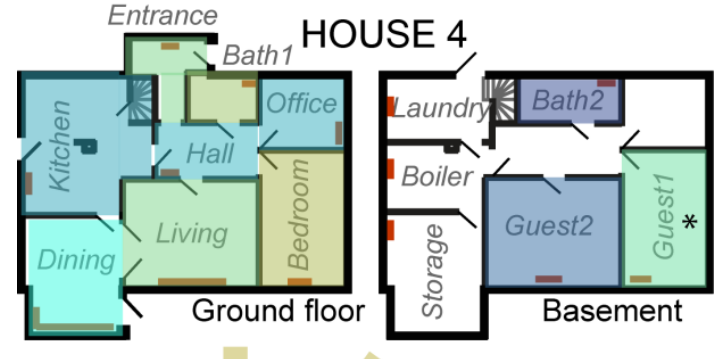

Overall return

- HOUSE 4
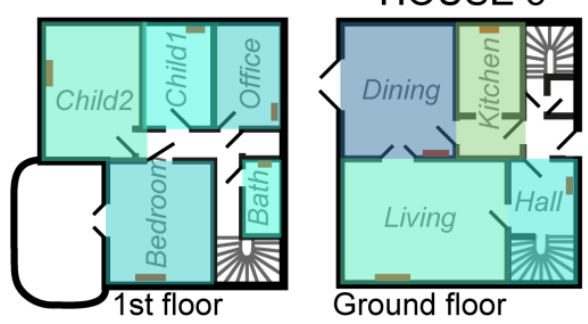

Ground floor

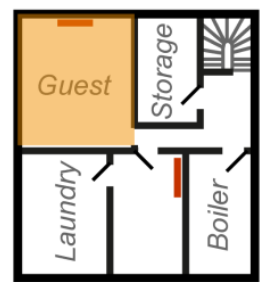

Basement
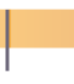

*Temperature averages for shorter periods due to logger failure and technical problems

Figure 5 Time-averaged radiator return temperatures in the houses from $1^{\text {st }}$ September 2015 to $1^{\text {st }}$ April 2016 


\subsection{Heating system malfunctions and errors}

Local problems in the heating systems that caused some radiators to have high return temperatures were investigated in detail. The analysis was based on a combination of measurements, occupant contact, and visits to the houses. The problems identified in the houses were grouped into three categories that are described and documented in the following sections:

1. Problems with thermostatic radiator valves

2. Problems regarding occupant behaviour

3. Problems with heating system design

\subsubsection{Thermostatic radiator valves}

In some of the houses, the occupants found themselves feeling cold when outdoor temperatures dropped at the beginning of October. The problem was found to be that thermostatic valves had become stuck in a closed position, which was quickly corrected by helping occupants to loosen the valves. However, we also found that the remounting of the thermostats afterwards was not always carried out correctly. The incorrect mounting led to a high return temperature and therefore to inefficient heating system operation. An example is shown in Figure 6 where return temperature in two rooms of House 1 were seen to increase to $33-37^{\circ} \mathrm{C}$ and afterwards drop to $20^{\circ} \mathrm{C}$ due to incorrect mounting of the thermostat and the correction of this. In some cases, the incorrect mounting was discovered by the occupants due to the resulting poor thermal comfort, but in other cases it was only revealed through the analysis of the measurements. This shows that this type of problem may occur without being noticed. Incorrect mounting was identified for both existing mechanical valves and for new electronic valves. 
House 1 - October 7th-11th 2015

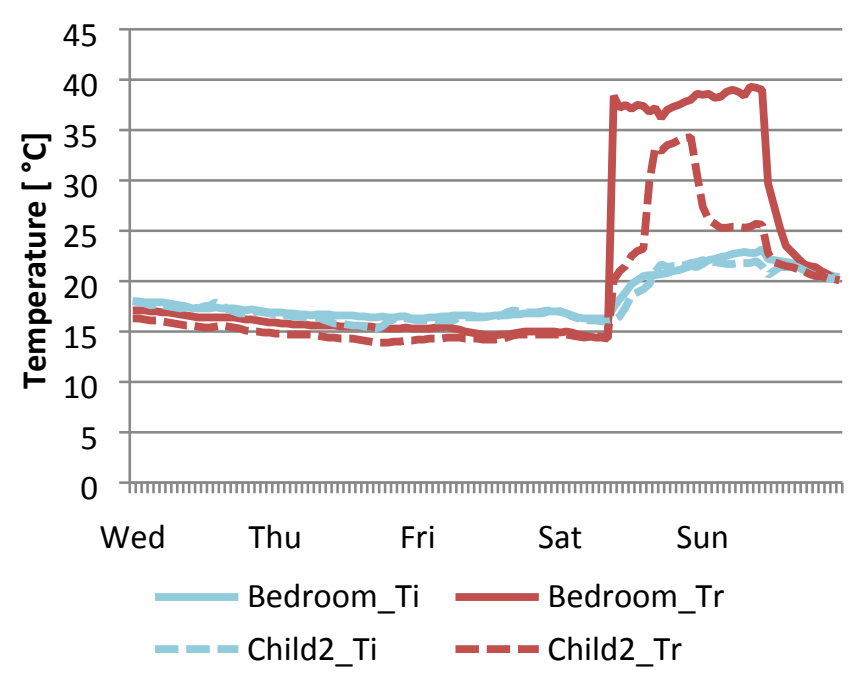

Figure 6 Low indoor temperature (Ti) due to stuck valves and high return temperature (Tr) due to wrongly mounted thermostats.

Shortly after the beginning of the heating season, measurements revealed that many of the thermostatic valves were worn or out-of-date in several of the houses, making the operation of the heating system inefficient. Many of the valves kept sticking or did not regulate the indoor temperature properly, and only some of the thermostatic valves in House 2 could be pre-set. This meant that the thermostatic valves in the remaining houses gave no opportunity to limit the mass flow through the radiators. Occupant behaviour, open windows, or malfunctions in one valve could therefore have a large effect on the return temperature of the overall heating system.

One general problem was found to be that occupants did not fully understand the functioning of the thermostatic radiator valves. Mechanical thermostatic radiator valves in Denmark are usually equipped with numbering from 1 to 5 , leading to the common belief that a high set-point means that the radiator will deliver more heat. While this is in some ways true, it does not always work as intended. Higher numbers mean that the thermostat seeks to maintain a higher indoor temperature set-point. If a set-point of 5 is chosen, this will typically cause the thermostatic valve to seek to achieve an indoor temperature of $25^{\circ} \mathrm{C}$. Most radiators are not designed to deliver such high indoor temperatures, so this will result in a constantly open valve, ultimately causing high return temperatures and occasionally overheating. Figure 7 shows two examples of changes in radiator return temperatures and indoor temperatures in rooms where the 
temperatures, not the indoor temperatures achieved.
House 4 - January 12th-16th 2016

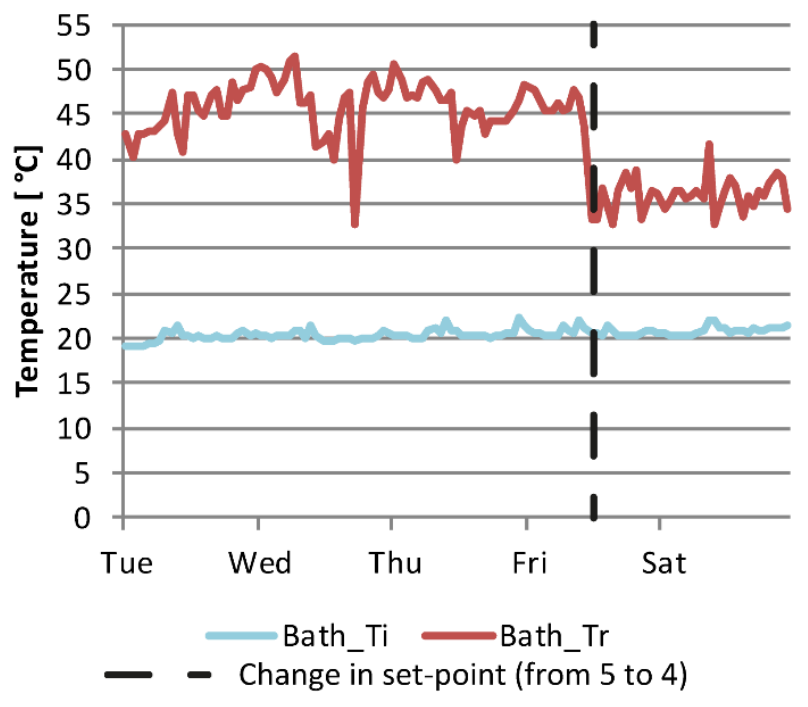

House 5 - February 9th-13th 2016

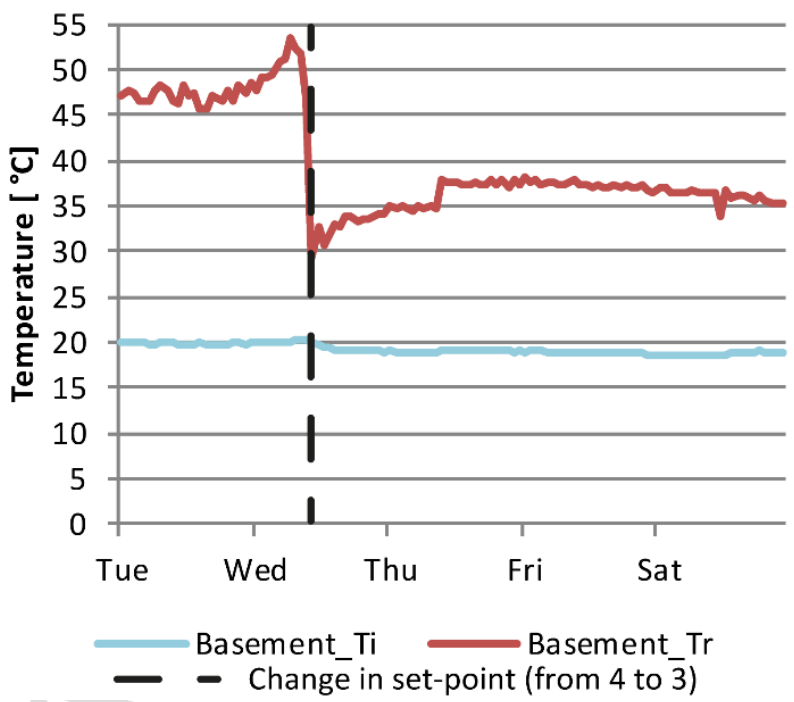

Figure 7 Examples of return temperatures $(\mathrm{Tr})$ and indoor temperatures (Ti) measured in rooms where the thermostatic valve was set on 5 and adjusted to 4 (left) or set on 4 and adjusted to 3 (right).

Another reoccurring problem in several of the houses investigated was that the thermostatic valves did not ensure the optimal balance of the water mass flow through the radiators. For rooms with more than one radiator or rooms that were connected through open doors, this meant that it was common that one radiator provided most of the heating in both cases, as illustrated in Figure 8. The figure shows how radiators in the same or adjacent rooms, have return temperatures that differ by $15-20^{\circ} \mathrm{C}$ for long periods. Here too, we found that a small change in thermostat set-point could have a large effect on the return temperature. Since the occupants are not provided with feedback on the operation of the radiators, this problem was mostly noticed through the measurements. Occupants would therefore be unlikely to react to the problem. And even if they did, they would not always find it easy to adjust the set-points and achieve a good balance. 
House 1 - January 5th-9th 2017

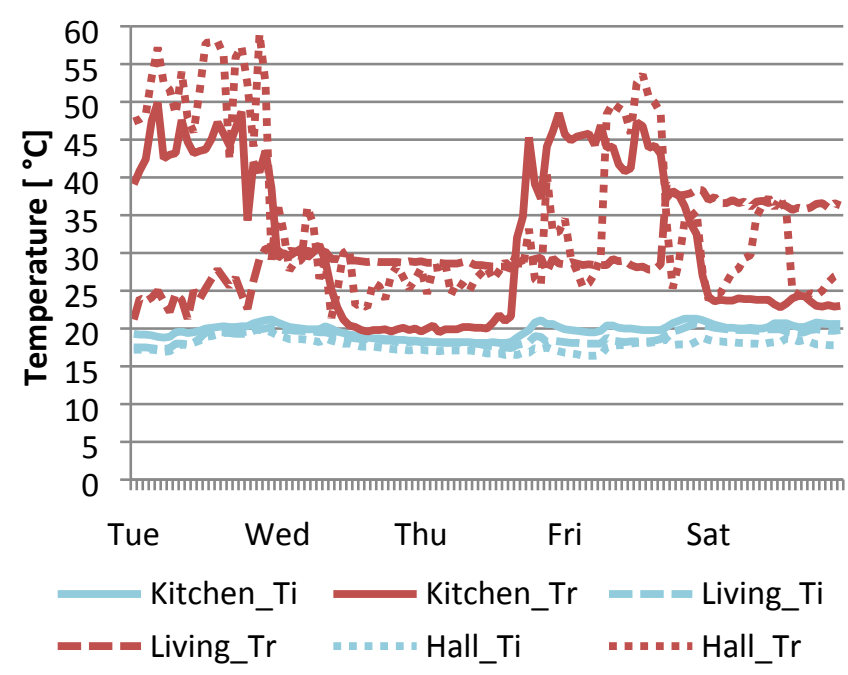

House 3 - November 23rd-28th 2015

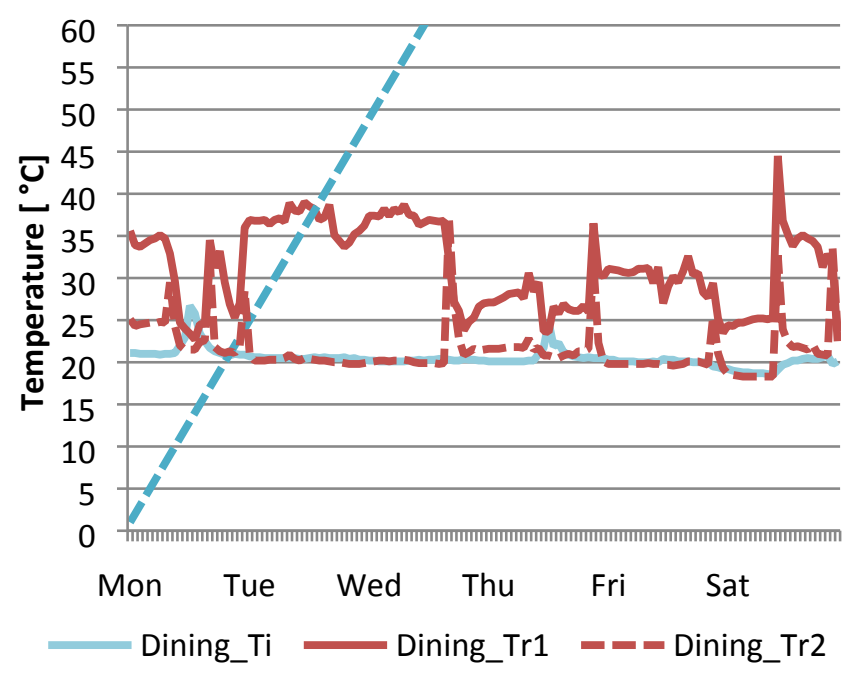

Figure 8 Examples of poor water mass flow balance between radiators in connected rooms. Left: three radiators in adjacent rooms that emit very different amounts of heat. Right: two radiators in the same room - only one seems to provide the heat.

\subsubsection{Occupant behaviour}

Occupants were generally found to have very different preferences on indoor temperature, with great impact on the heating system return temperatures. Where indoor temperatures were high, the radiator return temperatures were also often high. Conversely, where indoor temperatures were low, the heating system return temperature was generally lower. The relationship between indoor temperatures and radiator return temperatures depends on the dimensions of the radiators in the houses. Most of the radiators installed in the houses investigated were found to be unsuited to providing indoor temperatures of $23^{\circ} \mathrm{C}$ or higher from low-temperature heating. Figure 9 shows an example of the difference between the radiator return temperatures measured in a room with a low indoor temperature and a room with a high indoor temperature. 
House 1 - November 23rd-28th 2015

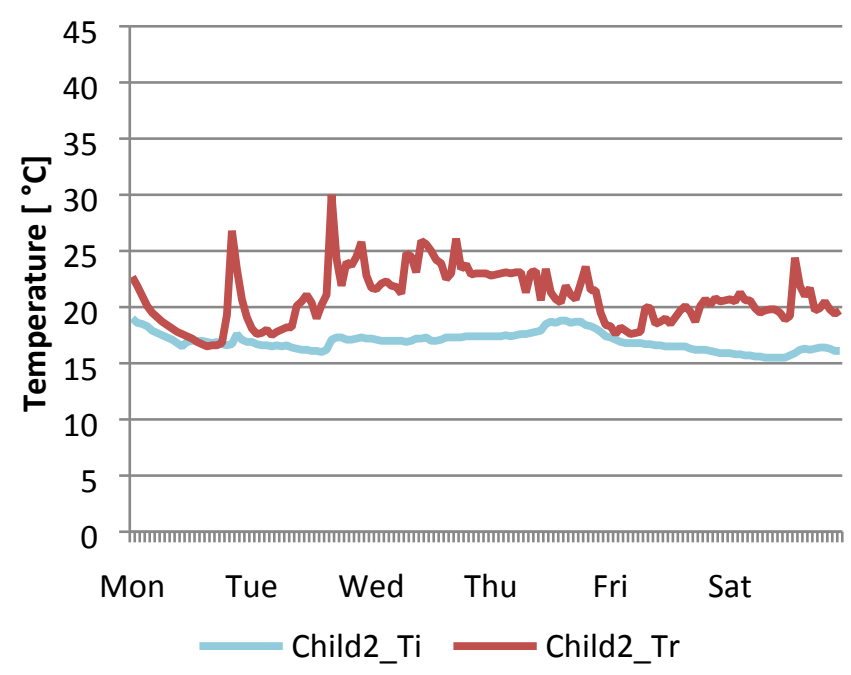

House 2 - January 11th-17th 2016

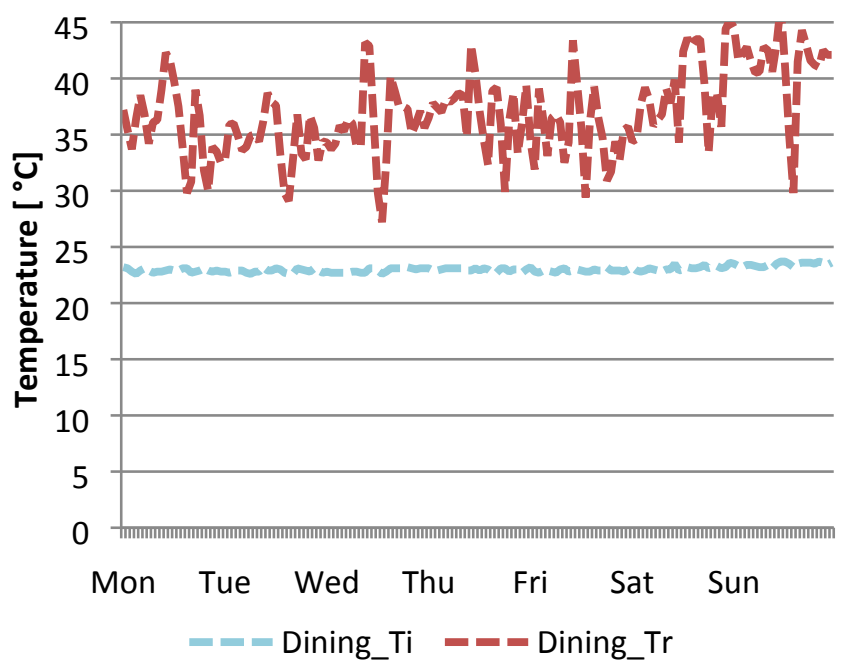

Figure 9 Example of radiator return temperatures (Tr) in a room with a low indoor temperature (Ti) (left) and in a room with a high indoor temperature (right).

The occupants in the houses investigated chose different indoor temperature set-points in the various rooms of their house - for example, the temperature set-point in living areas was often higher than that in bedrooms. In this situation, it would be best to keep doors between thermal zones closed, because open doors will cause radiators in warmer zones to partly heat the colder rooms. Nevertheless, keeping doors open can be a matter of preference, as was seen in House 2, where most doors where kept open, and the door to the basement was actually removed, due to the cat living in the house. Keeping doors open not only causes increased energy consumption due to indoor temperatures in some rooms being higher than necessary, but it may also lead to high heating system return temperatures because radiators are heating several rooms.

The indoor temperature set-points chosen are often a question of thermal preferences; however, we also found it was affected by a number of other factors. One example was that several occupants turned up the set-point of the thermostatic radiator valves during cold winter periods, even though maintaining the set-points should ensure the same indoor air temperature. This phenomenon can be easily explained because cold surfaces can lead to reduced operative indoor temperatures. Similar problems could arise in buildings with poor air tightness, where drafts could cause occupants to feel cold. Another example seen in some houses was that set-points were increased in some basement 
rooms in an attempt to remove moisture. These types of behaviour led to higher radiator return temperatures, especially where occupants chose a set-point of 5.

The energy-saving intentions of the occupants were also found to have a large effect on the chosen strategy for indoor temperature set-points. Examples were the use of night set-back systems and reduced indoor temperature set-points in rooms that were not in use. While there is always debate on whether reducing indoor temperatures for short periods can achieve energy savings, it is generally not desirable in small buildings connected to district heating systems. This is because the re-heating of rooms causes a peak in the heat demand, which leads to high return temperatures and requires larger dimensions of district heating pipes. Moreover, the periodical lowering of indoor temperatures typically decreases the thermal comfort of occupants. Figure 10 shows an example from House 3, where it can be seen how the overall space heating return temperature increases to $35-40{ }^{\circ} \mathrm{C}$, due to continuous re-adjustment of thermostat setpoints, and thereby peaks in the return temperatures of the living room, bedroom, and office.

House 3 - December 1st-2nd 2015

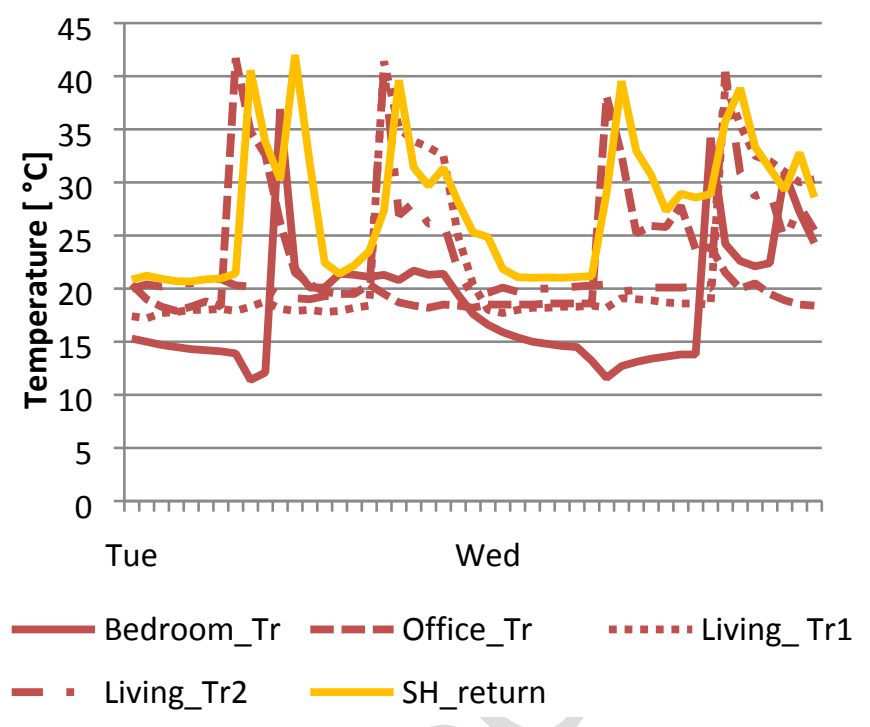

Figure 10 Example of how radiator return temperatures $(\mathrm{Tr})$ and the overall space-heating return temperature (SH_return) is affected by changing the set-points of thermostatic valves. 


\section{House 4 - November 23rd-29th 2015}

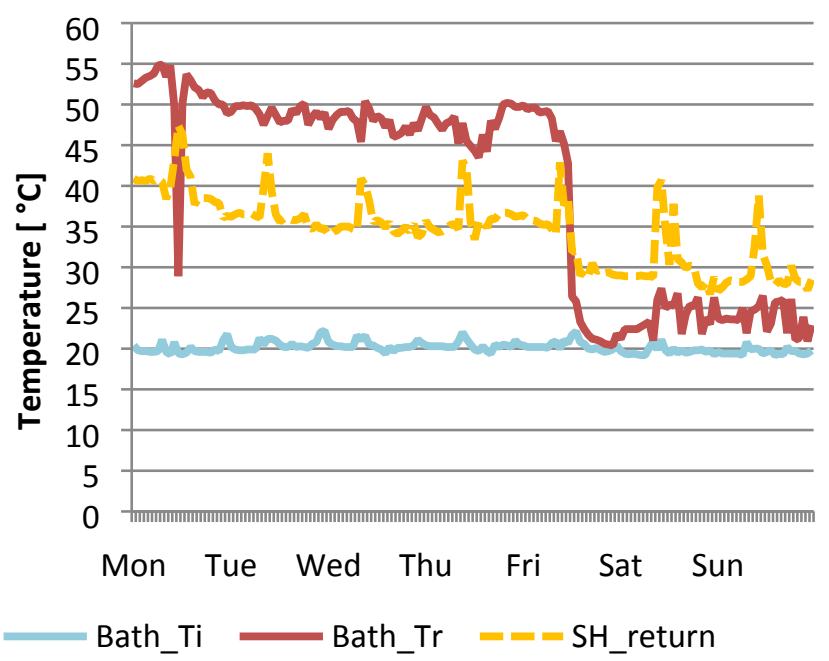

Figure 11 Drop in radiator return temperature ( $\mathrm{Tr}$ ) and overall space heating return temperature (SH_return) after removing cabinet door and loosening radiator valve in the bathroom of House 4.

In a few rooms in the houses, the radiators were found to be too small to satisfy even the basic thermal requirements of the occupants while still delivering a low radiator return temperature. This was the case where a radiator had been removed when two rooms were combined into one, when a radiator was installed in formerly unheated basement 


\section{House 1 - January 11th-12th 2016}

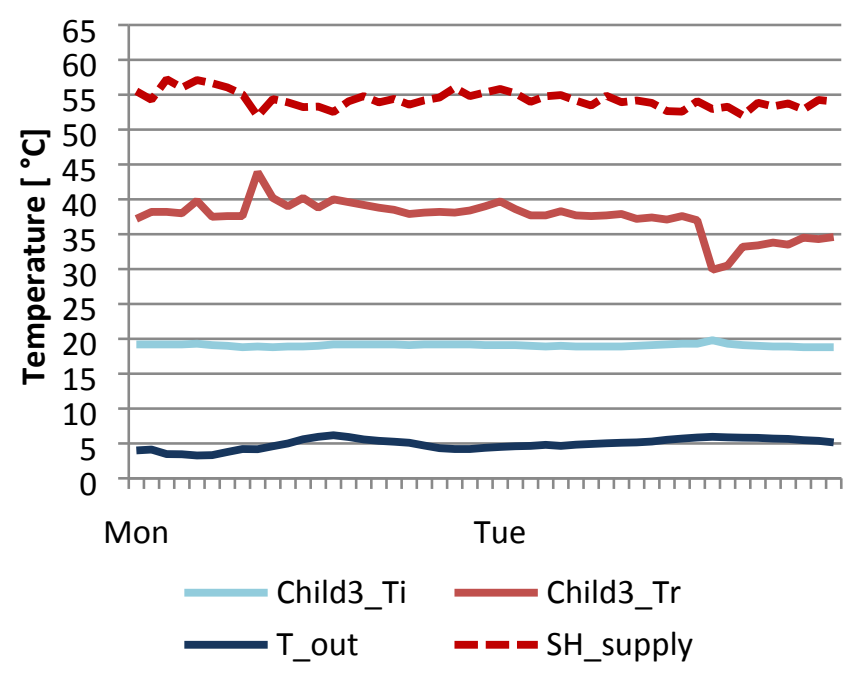

Figure 12 Example of a convector with high return temperature $(\mathrm{Tr})$, even when indoor temperature $(\mathrm{Ti})$ is below $20^{\circ} \mathrm{C}$, supply temperature is around $55^{\circ} \mathrm{C}$, and outdoor temperature is around $5{ }^{\circ} \mathrm{C}$.

\section{Discussion}

This study indicates that the existing single-family houses investigated may very well be heated with low supply temperatures, but not all of the existing heating systems are able to ensure a low return temperature. In some houses, local heating system problems need to be corrected to achieve return temperatures of $25-30^{\circ} \mathrm{C}$. This result is in line with recent studies of heating system temperatures in Multi-family dwellings in Sweden and Switzerland [10,11].

Similarly recent case studies of low-temperature district heating in Denmark has shown, that while supply temperatures can be lowered greatly, return temperatures are not always as low as expected $[32,40]$.

The causes for high return temperatures were investigated by measuring the radiator return temperatures, using loggers that were not very accurate, and tended to underestimate the measured temperatures. Despite of this underestimation, 
high return temperatures of above $40^{\circ} \mathrm{C}$ were still measured in the heating systems, and the measurements were still useful for comparison of radiator return temperatures and identification of large changes in return temperatures.

Nevertheless, it should be kept in mind, that the measured radiator return temperatures might be up to $5{ }^{\circ} \mathrm{C}$ lower than the actual temperatures. The local problems that led to high return temperatures were found to be mostly due to inefficient thermostatic radiator valves, inefficient occupant behaviour, and errors in heating system design. Correcting these types of errors may very well be possible without investing in a completely new heating system, but it would require the replacement of some heating system components and preferably further development of current thermostat design. This result is generally in line with previous research, that has shown how hydraulic balancing, proper pump settings, and installation of well-functioning TRVs can help improve the heating system operation of existing buildings and thereby lower the energy consumption for heating [18-20]. Only this study, adds to the reasoning that improved heating system operation is also important to obtain low district heating return temperatures, as also showed in a case study by Trüschel [21], and thereby enable the introduction of low-temperature district heating,.

One major problem was found to be excessive flow through individual radiators, caused by either poor radiator thermostat functionality or unintentional occupant behaviour. One solution to this problem could be to control the water mass flow to some extent, so that an individual radiator would not affect the entire heating system to a large degree. This might be achieved if new pre-settable radiator valves were installed. The result is in line with previous studies showing that TRVs are not necessarily suited to avoid excessive water mass flow [23] and that the installation of pre-set valves can limit excess water mass flows through radiators in an apartment building from a maximum of $300 \%$ to a maximum of $87 \%$ [25]. Installing new valves may also help ensure a smoother valve opening, which would also improve thermal comfort and lower the energy consumption. The solution is cheap and could be carried out as part of the general heating system maintenance over the years to come. However, it requires proper manual setting of the mass flow limitation, which can be difficult to ensure, as also referred through interviews in [11].

Another problem was due to limited user understanding of thermostat set-points and maintenance, as also reported in earlier studies $[11,16]$. This type of problem may be diminished by the introduction of electronic radiator valves, where the set-point is based on a temperature scale and the valve is automatically exercised to prevent it from sticking. 
However, the study found that even electronic valves had difficulty in ensuring low return temperatures, for example in cases where several radiators were heating the same room. It would therefore be good if current thermostat design could be further improved to include return temperature optimization. This functionality could help ensure that water mass flow is not only optimized for thermal comfort, but also with regard to return temperature. It would then be possible to prevent excessive water mass flows, imbalances between radiators, and unintentional occupant behaviour. This type of solution would also help avoid the high return temperatures and heat demand peaks associated with night set-back systems. Users would be able to stick to their desired set-back patterns and save energy, without causing increased energy consumption in the district heating network, by accepting a slower re-heating period started earlier in the night.

The main concern of the district heating company is to ensure proper thermal comfort for the customers. All the rooms in the connected houses should therefore be heated in accordance with occupant preferences, even when supply and return temperatures are lower. The study showed that in some houses this might require slight modification of the heating system. Larger heating surfaces should be installed where radiators are found to be unable to ensure thermal comfort and still deliver a low return temperature. This may be especially relevant in living areas, where a high indoor temperature is often preferred. Additionally, it may be relevant when the use of rooms have changed, and a basement room is suddenly heated or a radiator has been removed to combine two rooms. Occupants should be free to choose whatever aesthetic solution they prefer, including radiator concealers for example. In this case, thermal comfort and low return temperature should be ensured by installing remote temperature sensors (or perhaps by designing more aesthetic radiators). Finally, the study found that heating systems were often operated at high temperatures to compensate for discomfort from cold surfaces, drafts, or excessive moisture content. General energy saving and indoor climate measures, such as improving ventilation, reducing air leakages, and adding extra insulation in external walls and windows, are therefore important for ensuring the proper operation of low-temperature heating. Such measures can be taken as appropriate over the years to come and help to meet the goals of reduced energy consumption in buildings. Indeed, many occupants may find it more inviting to invest in private energy savings and improved indoor climate, rather than a new radiator. 
Investigations in this study regarded the heating systems of five single-family houses. These small heating systems may be quite different, than the heating systems in large multi-family dwellings, that are generally the most prevalent type of dwellings in dense cities supplied by district heating. However, the results of this study suggest, that the main problems in heating systems concern flow problems in radiator valves, occupant behaviour, and errors in heating system design. These types of problems could be expected to be even worse in multi-family dwellings. First of all, multi-family dwellings include a larger heating system and therefore it may be more complex to ensure proper flow through all radiator valves and obtain proper hydraulic balance. Secondly, multi-family dwellings consist of many different occupants, that may have very different habits and preferences. Consequently, as this study shows that inefficient control of one radiator may be problematic for a single-family house, it is likely that the inefficient control habits of one occupant could affect the overall heating system operation in the multi-family dwelling. Lastly, one learning from this study was, that it can be difficult to communicate with occupants and ensure that the correct measures are taken to improve heating system control. If this is difficult for a single-family house, it can be expected to be even more complicated in a multi-family dwelling, where different occupants need to agree on control strategies and central heating system improvements. Additionally, the individual occupants may not feel obliged to improve the overall heating system efficiency of the building, as they may feel less responsible for the overall energy consumption of the building and may not get proper feed-back on energy behaviour through current billing systems. As a conclusion, the results of this study suggest that there is a high likelihood, that the operation of heating systems in old multi-family dwellings can be improved drastically if design and operational errors were corrected. This aspect should however be investigated further.

\section{Conclusions}

In this study, we monitored the operation of the heating system in five Danish single-family houses from the 1930 s. We found that all the houses could be successfully heated with low supply temperatures. Two of the houses were also able to ensure low return temperatures, while the remaining three houses showed higher return temperatures than the preferred $25-30^{\circ} \mathrm{C}$. Measurements of individual radiator return temperatures were performed in order to evaluate how the operation of the individual radiators affected the overall heating system return temperature. Although these 
measurements did not have high accuracy, they proved useful to show large differences between radiator return temperatures and show how for example changes in thermostat set-points could cause large variations in the radiator return temperature. The heating system monitoring revealed two main barriers to achieving lower district heating return temperatures: lacking radiator heating power in the rooms of some houses, and a general problem of imperfect balancing and control of thermostatic radiator valves. To prepare all such houses for low-temperature district heating, two measures are therefore suggested. Firstly, under-dimensioned radiators should be replaced with radiators with a heating area large enough to ensure the thermal comfort of occupants. This is especially important in living areas, where thermal comfort is a major concern. Secondly, critical thermostatic radiator valves should be replaced. The most robust solution would be for a new electronic thermostatic valve to be developed that would optimize water mass flow with regard to both thermal comfort and optimal return temperature. In conclusion, the study indicates that the existing single-family houses investigated can certainly be heated with low-temperature district heating, though some of the houses have local heating system problems that must be fixed to ensure the preferred low return temperatures.

\section{Acknowledgement}

The work presented in this article was a result of the research activities of the Strategic Research Centre for 4th Generation District Heating (4DH), which received funding from the Innovation Fund Denmark.

A special thank-you is due to Gentofte Fjernvarme and the occupants in the case houses for supporting and participating in the project. This research project would not have been possible without their help and time. 


\section{References}

[1] Danish Energy Agency and EUDP 2010-II. Guidelines for Low-Temperature District Heating. 2014.

[2] Danish Energy Agency, EUDP 2008-II. CO2-reductions in low energy buildings and communities by implementation of low-temperature district heating systems. Demonstration cases in EnergyFlexHouse and Boligforeningen Ringgården - Journalnr. 63011-0152. DTU BYG: 2011.

[3] Danish Energy Agency. Energy statistics 2013. 2014.

[4] Dansk Fjernvarmes F\&U konto. Varmeplan Danmark 2008 [Heating Plan Denmark 2008]. 2008.

[5] Lund H, Werner S, Wiltshire R, Svendsen S, Thorsen JE, Hvelplund F, et al. 4th Generation District Heating (4GDH): Integrating smart thermal grids into future sustainable energy systems. Energy 2014;68:1-11. doi:10.1016/j.energy.2014.02.089.

[6] Østergaard DS, Svendsen S. Theoretical overview of heating power and necessary heating supplytemperatures in typical Danish single-family houses from the 1900s. Energy Build 2016;126:375-83.

[7] Østergaard DS, Svendsen S. Replacing critical radiators to increase the potential to use low-temperature district heating - A case study of 4 Danish single-family houses from the 1930s. Energy 2016;110:75-84. doi:10.1016/j.energy.2016.03.140.

[8] Brand M, Svendsen S. Renewable-based low-temperature district heating for existing buildings in various stages of refurbishment. Energy 2013;62:311-9. doi:10.1016/j.energy.2013.09.027.

[9] Wang Q, Ploskić A, Holmberg S. Retrofitting with low-temperature heating to achieve energy-demand savings and thermal comfort. Energy Build 2015;109:217-29. doi:10.1016/j.enbuild.2015.09.047.

[10] Jangsten M, Kensby J, Dalenbäck JO, Trüschel A. Survey of radiator temperatures in buildings supplied by district heating. Energy 2017;137:292-301. doi:10.1016/j.energy.2017.07.017.

[11] Averfalk H, Werner S, Felsmann C, Rühling K, Wiltshire R, Svendsen S, et al. Annex XI final report: Transformation Roadmap from High to Low Temperature District Heating Systems. 2017.

[12] Gadd H. To analyse measurements is to know! Ph.D. thesis, Lund University, 2014.

[13] Gadd H, Werner S. Achieving low return temperatures from district heating substations. Appl Energy 2014;136:59-67. doi:10.1016/j.apenergy.2014.09.022.

[14] Gadd H, Werner S. Heat load patterns in district heating substations. Appl Energy 2013;108:176-83. doi:10.1016/j.apenergy.2013.02.062.

[15] Petersson S, Werner S. Långtidsegenskaper hos lågflödesinjusterade radiatorsystem. 2003.

[16] Peeters L, Van der Veken J, Hens H, Helsen L, D'haeseleer W. Control of heating systems in residential buildings: Current practice. Energy Build 2008;40:1446-55. doi:10.1016/j.enbuild.2008.02.016.

[17] Liao Z, Swainson M, Dexter AL. On the control of heating systems in the UK. Build Environ 2005;40:343-51. doi:10.1016/j.buildenv.2004.05.014.

[18] Ahern C, Norton B. Energy savings across EU domestic building stock by optimizing hydraulic distribution in domestic space heating systems. Energy Build 2015;91:199-209. doi:10.1016/j.enbuild.2015.01.014.

[19] Monetti V, Fabrizio E, Filippi M. Impact of low investment strategies for space heating control: Application of thermostatic radiators valves to an old residential building. Energy Build 2015;95:202-10. 
doi:10.1016/j.enbuild.2015.01.001.

[20] Cholewa T, Siuta-Olcha A, Balaras CA. Actual energy savings from the use of thermostatic radiator valves in residential buildings - Long term field evaluation. Energy Build 2017;151:487-93. doi:10.1016/j.enbuild.2017.06.070.

[21] Trüschel A. Värdet av injustering [The value of balancing]. Svensk Fjärrvärme [Swedish District Heating]; 2005.

[22] Xu B, Fu L, Di H. Dynamic simulation of space heating systems with radiators controlled by TRVs in buildings. Energy Build 2008;40:1755-64. doi:10.1016/j.enbuild.2008.03.004.

[23] Xu B, Huang A, Fu L, Di H. Simulation and analysis on control effectiveness of TRVs in district heating systems. Energy Build 2011;43:1169-74. doi:10.1016/j.enbuild.2010.08.030.

[24] Tunzi M, Østergaard DS, Svendsen S, Boukhanouf R, Cooper E. Method to investigate and plan the application of low temperature district heating to existing hydraulic radiator systems in existing buildings. Energy 2016;113:413-21. doi:10.1016/j.energy.2016.07.033.

[25] Piana EA, Grassi B, Bianchi F, Pedrotti C. Hydraulic balancing strategies: A case study of radiator-based central heating system. Build Serv Eng Res Technol 2018:1-14. doi:10.1177/0143624417752830.

[26] Rhee KN, Yeo MS, Kim KW. Evaluation of the control performance of hydronic radiant heating systems based on the emulation using hardware-in-the-loop simulation. Build Environ 2011;46:2012-22. doi:10.1016/j.buildenv.2011.04.012.

[27] Tahersima F, Stoustrup J, Rasmussen H. An analytical solution for stability-performance dilemma of hydronic radiators. Energy Build 2013;64:439-46. doi:10.1016/j.enbuild.2013.05.023.

[28] Seifert J, Knorr M, Meinzenbach A, Bitter F, Gregersen N, Krogh T. " Review of thermostatic control valves in the European standardization system of the EN 15316-2 / EN 215 ." Energy Build 2016;125:55-65. doi:10.1016/j.enbuild.2016.04.066.

[29] Bekö G, Lund T, Nors F, Toftum J, Clausen G. Ventilation rates in the bedrooms of 500 Danish children. Build Environ 2010;45:2289-95. doi:10.1016/j.buildenv.2010.04.014.

[30] Danish Energy Agency. Håndbog for energikonsulenter. Enfamiliehuse. Beregnet forbrug - 2012 [Handbook for energy consultants. Single-family houses. Calculated consumption - 2012]. 2012.

[31] Brand M, Thorsen JE, Svendsen S, Christiansen $\mathrm{CH}$. A direct heat exchanger unit used for domestic hot water supply in a single-family house supplied by low energy district heating. 12th Int. Symp. Dist. Heat. Cool., 2010.

[32] Danish Energy Agency, EUDP 2010-II. Demonstration i Lystrup - Fuldskalademonstration af lavtemperaturfjernvarme i eksisterende bebyggelser - Journalnr. 64010-0479 [Demonstration in Lystrup - Full scale demonstration of low-temperature district heating in existing building areas]. 2014.

[33] Brunata. Brunata FuturaComfort+ data sheet n.d. http://brunata.gr/fileadmin/datasheets/UK/uk-qb101012.pdf (accessed April 25, 2018).

[34] Danish Standard. DS/EN ISO 9001:2015 - Quality management systems - Requirements. 2015.

[35] Danish Standard. DS/EN 834:2013 - Heat cost allocators for the determination of the consumption of room heating radiators - Appliances with electrical energy supply. 2013.

[36] Danfoss. ECL Comfort 310 n.d. http://products.danfoss.co.uk/productrange/list/heatingsolutions/weathercompensators/ecl-comfort-310/\#/. 
513 [37] Danfoss. ESMC Surface sensor n.d.

514

[38] Hasan A, Kurnitski J, Jokiranta K. A combined low temperature water heating system consisting of radiators and floor heating. Energy Build 2009;41:470-9. doi:10.1016/j.enbuild.2008.11.016.

[39] Olesen BW, Mortensen E, Thorshauge J, Berg-Munch B. Thermal Comfort in a Room Heated by Different Methods - Technical paper no. 2256. Los Angeles Meet. ASHRAE Trans. 86, 1980, p. 34-48.

[40] Danish Energy Agency, EUDP 2010-II. Demonstration i Sønderby - Fuldskalademonstration af lavtemperaturfjernvarme i eksisterende bebyggelser - Journalnr. 64010-0479 [Demonstration in Sønderby - Full scale demonstration of low-temperature district heating in existing buildings]. 2014. 


\section{Highlights:}

- Existing houses can be heated with low supply temperatures for most of the year

- Errors in few radiators can cause high heating system return temperature

- Heating system return temperatures in 2 of 5 investigated houses are below $35^{\circ} \mathrm{C}$

- Proper heating system control is key to obtain low return temperatures 